\title{
EXPOSURE TO ACELLULAR BLOOD PRODUCTS AND RISK OF HIV INFECTION IN HEMOPHILIACS FROM BELO HORIZONTE, BRAZIL
}

\author{
Fernando A. PRoletTi (1, 5), Anna Barbara F. C. PRoIETTI (2), Maria Fernanda F. L. CoSTA (3), Carlos M. F. \\ ANTUNES (4, 5), Mark D. C. GUIMARÁES $(3,5)$, Urquiza H. M. PAUlino (1), Caio J. C. SOUZA (2), \\ Laércio MELO (2) \& Álvaro MUÑOZ (5)
}

\begin{abstract}
SUMMARY
Results of a HIV prevalence study conducted in hemophiliacs from Belo Horizonte, Brazil are presented. History of exposure to acellular blood components was determined for the five year period prior to entry in the study, which occurred during 1986 and 1987. Patients with coagulations disorders (hemophilia $\mathrm{A}=132$, hemophilia $\mathrm{B}=16$ and coagulation disorders other than hemophilia $=16$ ) were transfused with liquid cryoprecipitate, locally produced, lyophilized cryoprecipitate, imported from Sāo Paulo (Brazil) and factor VIII and IX, imported from Rio de Janeiro (Brazil), Europe, and United States. Thirty six $(22 \%)$ tested HIV seropositive. The univariate and multivariate analysis (logistic model) demonstrated that the risk of HIV infection during the study period was associated with the total units of acellular blood components transfused. In addition, the proportional contribution of the individual components to the total acellular units transfused, namely a increase in factor VIII/IX and lyophilized cryoprecipitate proportions, were found to be associated with HIV seropositivity. This analysis suggest that not only the total amount of units was an important determinant of HIV infection, but that the risk was also associated with the specific component of blood transfused.
\end{abstract}

KEY WORDS: Hemophiliacs; HIV; blood products; Brazil.

\section{INTRODUCTION}

Since the onset of the AIDS epidemic, hemophiliacs were recognized as a group at risk for HIV infection due to their frequent use of large volumes of blood and blood products and consequent cumulative exposure throughout life to thousands of different donors ${ }^{4,6,8}$. With the implementation of HIV antibody screening of the blood donated, the risk of transfusion-associated AIDS has been dramatically reduced, especially for the hemophiliac population.

Sponsored by Financiadora de Estudos e Projetos (FINEP) and Coordenadoria de Aperfeiçoamento de Pessoal de Nível Superior (CAPES), Brazil.

(1) Dep. Propedéutica Complementar, Universidade Federal de Minas Gerais, Brazil.

(2) Fundação Hemominas, Minas Gerais, Brazil.

(3) Dep. Medicina Preventiva Social, Universidade Federal de Minas Gerais, Brazil.

(4) Dep. Parasitologia, Universidade Federal de Minas Gerais, Brazil.

(5) Dep. of Epidemiology, Johns Hopkins School of Hygiene and Public Health, Baltimore, USA.

Address for correspondence: Fernando A. Proietti M. D. ScM. Johns Hopkins School of Hygiene and Public Health. 615 North Wolfe St. Mail Box 442. Baltimore, MD 21205 - USA. 
PROIETTI, F. A.; PROIETTI, A. B. F. C.; COSTA, M. F. F. L.; ANTUNES, C. M. F.; GUIMARÃES, M. D. C.; PAULINO, U. H. M.; SOUZA, C. J. C.; MELO, L. \& MUNOZ, A. - Exposure to acellular blood products and risk of HIV infection in hemophiliacs from Belo Horizonte, Brazil. Rev. Inst. Med. trop. S. Paulo, 34(3): 227-232, 1992.

We report here the results of a HIV prevalence study conducted in hemophiliacs from Belo Horizonte Brazil, from October 1985 to August 1987. Hemophiliacs were treated with acellular blood components of different types and geographical origin. The acellular blood components more frequently transfused were: (a) liquid cryoprecipitate, produced locally; (b) lyophilized cryoprecipitate imported from São Paulo, and (c) factor VIII and factor IX commercially produced and imported from Rio de Janeiro and from outside the country(United States and Europe).

The objective of the study was to determine the association between exposure to the different acellular blood components, and risk for HIV infection for the five year period before 1986 to 1987 inclusive, when the screening for HIV antibody in the blood donated was not yet fully implemented.

\section{MATERIAL AND METHODS}

Study population and design

Belo Horizonte, with about 2.5 million inhabitants in 1986/87, is the main city of Minas Gerais State, in the southeast of Brazil. The first AIDS case in Minas Gerais was reported in 1983 and, as of June 1987, 55 patients with AIDS and 37 with ARC were reported in the State; $4 \%$ of all cases were hemophiliacs and the remainder distributed among homosexual/bisexual men, recipients of blood transfusion and intravenous drug users ${ }^{2}$.

The study was conducted at Hemominas, a blood center unit sponsored by public funds of Minas Gerais State. Hemominas became operational in 1984, and one of its objectives is to provide and centralize comprehensive care to hemophiliacs. Hemominas is the only health service in Belo Horizonte specialized in outpatient medical attention to hemophiliacs.

One hundred and sixty four patients (hemophilia $A=132$, hemophilia $B=16$, coagulation disorders other than hemophilia $=16$ ), were interviewed and had a blood sample drawn. The patients were invited to participate in the study either during their visits to Hemominas, for treatment of coagulation related problems and its sequelae, or by mail. Although the exact number of hemophiliacs in Belo Horizonte is not known and there is not a population frame from which to sample, the individuals enrolled in this study are thought to be representative of the hemophiliacs with severe forms of the disease requiring closer medical attention, from Hemominas health care staff.

\section{Survey Data}

Information was obtained about age, sex, race, marital status, education, income, employment status, hospitalizations in the last 5 years prior interview, sexual activity, intravenous drug abuse and transfusion with clotting-factor concentrates (factor VIII, factor IX, liquid cryoprecipitate and lyophilized cryoprecipitate) for the 5 years period prior to enrollment in the study.

\section{Laboratory Methods}

Serum samples were tested for the presence of HIV antibodies by enzyme immunoabsorbent assay, EIA (Salk Dupont) and by Western blot (Dupont/Biotech), according to manufacturer instructions. Specimen reactive in two EIA and confirmed by the Western blot were considered positive for HIV antibodies.

\section{Statistical Analysis}

Standard statistical measures of location and scale (e. g. means and variance) were used to describe the data. To compare the seropositive and seronegative according to the type and number of units received, we first computed the percentage receiving acellular blood products. Subsequently, we computed the composition of units according to type for those receiving acellular blood products.

To adjust for the total number of acellular blood components units administered, we created a variable named total acellular blood units. For the $i^{\text {th }}$ individual, total acellular blood units is equal to the sum of liquid cryoprecipitate, lyophilized cryoprecipitate, and factor VIII/IX units (factor VIII/IX = factor VIII + factor IX units). Each component was further expressed as proportion of total acellular units. For example, for 
PROIETTI, F. A.; PROIETTI, A. B. F. C.; COSTA, M. F. F. L.; ANTUNES, C. M. F.; GUIMARÄES, M. D. C.; PAULINO,

U. H. M.; SOUZA, C. J. C.; MELO, L. \& MUNOZ, A. - Exposure to acellular blood products and risk of HIV infection in hemophiliacs from Belo Horizonte, Brazil. Rev. Inst. Med. trop. S. Paulo, 34(3): 227-232, 1992.

the $\mathrm{i}^{\text {th }}$ hemophiliac, the contribution of liquid cryoprecipitate to the total acellular units used was: proportion of liquid cryoprecipitate $=1 \mathrm{i}$ quid cryoprecipitate units/total acellular units.

In order to determine the relative importance of each acellular blood component transfused (liquid cryoprecipitate, lyophilized cryoprecipitate, factor VIII/IX) a logistic regression model ${ }^{1}$ was fitted to the data, with HIV serostatus (positive/negative) as the outcome and the different acellular blood components as explanatory variables.

To account for the skewed distribution of the total units transfused, we took the logarithm base 10 of (total acellular units +1 ). The final model fitted to the data has HIV as the outcome and logarithm base 10 of total acellular units, proportion of lyophilized cryoprecipitate, proportion of factor VIII/IX and proportion of liquid cryoprecipitate as the explanatory variables. Given that the proportions of acellular units according to type add to one, we used two proportions - lyophilized cryoprecipitate and factor VIII/IX - for the three categories (i.e. liquid cryoprecipitate, lyophilized cryoprecipitate and factor VIII/IX); the liquid cryoprecipitate proportion was used as the reference category. The inter cept of the logistic regression refers to an individual receiving $100 \%$ of the acellular units as liquid cryoprecipitate.

\section{RESULTS}

Thirty six patients $(36 / 164,22.0 \%)$ tested HIV seropositive; none had a diagnosis of ARC or AIDS at enrollment in the study. Table 1 shows the age distribution and diagnosis by HIV serostatus. The two groups were similar with respect to age and hemophilia A diagnosis, but among patients with a diagnosis of hemophilia $\mathbf{B}$, a higher proportion was HIV seropositive. None of the patients in the category "other diagnosis" were HIV seropositive.

There was no report of intravenous drug use or homosexual activity. Individuals with "other diagnosis" were excluded from further analysis.

Table 2 displays the median and range for the total acellular units used, proportion of lyo-
TABLE 1

Descriptive statistics by HIV serostatus for patients with coagulation disorders in Belo Horizonte, Brazil, 1985-1987.

\begin{tabular}{lcc}
\hline Variable & $\begin{array}{c}\text { HIV seropositive } \\
(\mathrm{N}=36)\end{array}$ & $\begin{array}{c}\text { HIV seronegative } \\
(\mathbf{N}=128)\end{array}$ \\
\hline $\begin{array}{l}\text { Age years* } \\
\text { Diagnosis } \\
\text { Hemophilia A } \\
\text { Hemophilia B } \\
\text { Other** }\end{array}$ & $17.8 \pm 9.6$ & $17.1 \pm 11.8$ \\
\hline
\end{tabular}

*: mean $\pm \mathrm{SD}$

**: Glanzmann's Thromboasthenia (16 patients); Congenital Hypofibrinogenemia (2); Von Willebrand (2); Hereditary Hemorrhagic Teleangectasia (1); and indeterminate (5).

TABLE 2

Distribution of clotting-factor concentrate by HIV serostatus in hemophiliacs from Belo Horizonte, Brazil, 1985-1987.

\begin{tabular}{|c|c|c|}
\hline Variable & $\begin{array}{l}\text { HIV seropositive } \\
\qquad(\mathbf{N}=\mathbf{2 8})^{*}\end{array}$ & $\begin{array}{l}\text { HIV seronegative } \\
\qquad(\mathrm{N}=96)^{*}\end{array}$ \\
\hline Total acellular units** & $60,500(0-386,000)$ & $9,800(0-310,000)$ \\
\hline Total acellular $=0$ & $7.1 \%$ & $9.4 \%$ \\
\hline Total acellular $>0$ & $92.9 \%$ & $90.6 \%$ \\
\hline \multicolumn{3}{|c|}{$\begin{array}{l}\text { Composition for those with total acellular }>0 \text { : } \\
\text { Lyophilized }\end{array}$} \\
\hline cryoprecipitate & $16.8 \%$ & $5.0 \%$ \\
\hline $\begin{array}{l}\text { Factor VIII/IX } \\
\text { Liquid }\end{array}$ & $33.9 \%$ & $16.2 \%$ \\
\hline cryoprecipitate & $49.2 \%$ & $78.8 \%$ \\
\hline
\end{tabular}

*: missing data on $8(22 \%)$ hemophiliacs HIV seropositive and $16(14 \%)$ hemophiliacs HIV seronegative; 16 with "other diagnosis" excluded.

**: Total acellular units = Lyophilized cryoprecipitate $+\mathrm{Li}$ quid cryoprecipitate + Factor VIII/IX; values given are median and range.

TABLE 3

Regression coefficients and standard error using logistic regression to estimate probability of HIV infection among hemophiliacs from Belo Horizonte, Brazil, 1985-1987.

\begin{tabular}{lccc}
\hline Variable & Coefficient & Std error & p value \\
\hline $\begin{array}{l}\text { Intercept } \\
\text { Total acellular units }\end{array}$ & $-1.75^{*}$ & & \\
(in log 10$)-4$ & 0.45 & 0.25 & 0.07 \\
$\begin{array}{l}\text { Lyophilized } \\
\text { cryoprecipitate** }\end{array}$ & & & \\
Factor VIII/IX** & 2.07 & 0.93 & 0.03 \\
& 1.32 & 0.63 & 0.04 \\
\hline
\end{tabular}

*: corresponds to total acellular units $=10,000(4$ in $\log 10)$ and $100 \%$ of them are liquid cryoprecipitate. In this case, the estimate probability of seropositivity is: $1 /[1+$ exp $(1.75)]=15 \%$

**: as the proportion of the total acellular units transfused. 
PROIETTI, F. A.; PROIETTI, A. B. F. C.; COSTA, M. F. F. L.; ANTUNES, C. M. F.; GUIMARÄES, M. D. C.; PAULINO, U. H. M.: SOUZA, C. J. C.; MELO, L. \& MUNOZ, A. - Exposure to acellular blood products and risk of HIV infection in hemophiliacs from Belo Horizonte, Brazil. Rev. Inst. Med. trop. S. Paulo, 34(3): 227-232, 1992.

philized cryoprecipitate, factor VIII/IX, liquid cryoprecipitate, by HIV serostatus. One hundred and twenty four hemophiliacs ( $28 \mathrm{HIV}$ positive and 96 HIV negative) had complete data on acellular blood components units and are the ones used for the logistic regression analysis.

The results indicate that the HIV seropositive hemophiliacs were exposed on average, to more units of acellular blood components. A slightly higher percentage of HIV seronegative did not receive acellular products. However, among those receiving acellular products, the HIV seropositive on average were exposed to a higher proportion of factor VIII/IX and lyophilized cryoprecipitate, as compared to the HIV seronegative, who as a group were more likely to have used a higher proportion of liquid cryoprecipitate.

Table 3 displays the results of the logistic regression analysis. Although the total number of units used is associated with HIV seropositivity, the proportional contribution of the different acellular blood components to the total acellular units used are independently associated with the risk of HIV infection. The probability of seropositivity is equal to $73.7 \%$, for an individual receiving 380,000 units of acellular blood products and $100 \%$ of them being lyophilized cryoprecipitate.

To illustrate the effect of the types of units received, we took two hemophiliacs receiving the same amount of total acellular units. The first one has a total acellular proportional distribution as follow: proportion of lyophilized cryoprecipitate equal 0.50 , proportion of fáctor VIII/ IX equal 0.40 and proportion of liquid cryoprecipitate equal 0.10 , and the second one with 0.30 for lyophilized cryoprecipitate, $\mathbf{0 . 3 0}$ for factor VIII/IX and 0.40 for liquid cryoprecipitate. The odds ratio for HIV seropositivity, adjusted for the total acellular units used is $1.7(95 \% \mathrm{CI}=$ $1.2,2.6)$.

\section{DISCUSSION}

The results of this study are in agreement with the literature reporting a higher risk of HIV infection to hemophiliacs exposed to large numbers of clotting-factor units ${ }^{3}, 5,7,8,10$, and the introduction of the AIDS virus in a hemophiliac population of a given region by blood products coming from abroad?

In Belo Horizonte, the use of imported cryoprecipitate and clotting-factor concentrates, like factor VIII or factor IX is expensive for both the individual hemophiliac and the health care system. As a result of this economical constraint, the locally produced liquid cryoprecipitate was the more frequently used acellular blood component, with $81.1 \%$ (133/164) patients reporting use of liquid cryoprecipitate at least once; for factor VIII/IX and lyophilized cryoprecipitate the proportions were $40.7 \%(66 / 162)$ and $25.2 \%$ (40/159) respectively.

Exposure to acellular blood components produced inside the country, as opposed to imported blood products, should not represent a important risk factor for HIV infection to hemophiliacs in Brazil, at least during the early stages of the AIDS epidemic in the country, even before the implementation of HIV screening in the blood donated. The statistically significant coefficients associated with lyophilized cryoprecipitate, imported from São Paulo, and factor VIII/ IX, imported from the United States, Europe and Rio de Janeiro indicates that the risk of HIV infection for hemophiliacs living in Belo Horizonte, during the study period: a) was independent of a particular local from where the acellular blood component was imported; and b) is associated with the total number of acellular blood components units to which the hemophiliac were exposed, and also with the proportional contribution of the individual components to the total acellular units transfused, namely a increase in factor VIII/IX and lyophilized cryoprecipitate proportions, as opposed to liquid cryoprecipitate locally produced.

The study has some limitations. All the information about number of units used was obtained by interview, relying on the memory of the hemophiliac, to quantify the amount of units to which one was exposed during a window period up to five years before interview, implying possible memory failure. It is conceivable that some of the hemophiliacs were concerned about HIV and the possibility of been infected, resulting in possible associated recall bias and differential 
PRoIetTi, F. A.; PROIETTI, A. B. F. C.; COSTA, M. F. F. L.; ANTUNES, C. M. F.; GUimaRĀES, M. D. C.; PAULINO, U. H. M.; SOUZA, C. J. C.; MELO, L. \& MUÑOZ, A. - Exposure to acellular blood products and risk of HIV infection in hemophiliacs from Belo Horizonte, Brazil. Rev. Inst. Med. trop. S. Paulo, 34(3): 227-232, 1992.

misclassification in the assessment of exposure to blood products. Although this misclassification may have occurred, it is less likely that it had affected the estimation of exposure to the individual components of the total units transfused.

We made the assumption that the risk of HIV infection was a function of the cumulative amount of acellular units and the different components to which hemophiliacs were exposed. The five year period for which exposure was quantified included the phase in that HIV screening of the blood donated was been implemented, inside Brazil and abroad. Ideally, we would like to determine and quantify, the exact moment and amount of blood components transfused each time to a given hemophiliac. As this was not possible, the model does not take in to account that the likelihood of blood products being contaminated, and hence been a vehicle for HIV transmission, may be time-dependent during the study period. Also, information about exposure to cellular blood components was not obtained. Consequently, in terpretation and generalined. Consequently, interpretation and generalizability of the study findings should be done with caution.

The modelling used allowed us to discriminate and quantify the individual contribution of each acellular blood components to the probability of HIV infection, after adjusting for the total amount of units transfused. This analytical approach has application to other situations when a continuous variable can be segregated in its individual and mutually exclusive components that add to one. To avoid tautologies the investigator should exclude one of the categories from the model which will correspond to the intercept in the regression equation.

In summary, our results suggest that HIV was introduced in the Belo Horizonte hemophiliac population by acellular blood components imported from the United States and Europe, and concomitantly, by blood products imported from Rio de Janeiro and São Paulo.

Great caution is necessary in donor selection and screening of the blood donated in Brazil to avoid transmission of HIV, due to the fact that the risk of HIV infection to hemophiliacs, associated with the use of lyophilized cryoprecipitate, obtained from a markedly lower number of donors as compared to concentrate factors, was as important as the risk for those exposed to factor VIII and IX.

It is likely that the full implementation of HIV screening in the blood supply in Brazil in the mid 80's, and a more rigorous donor selection policy, have had a major impact in changing the safety of the blood supply. Future investigations will determine if this measures reduced the risk of HIV transmission to hemophiliacs by blood and blood products to a minimum.

\section{RESUMO}

Exposição de produtos do sangue, acelulares e o risco da infecção pelo VIH, em hemofilicos de Belo Horizonte, Brasil

Resultados de um estudo da prevalência de infecção pelo VIH, realizado em hemofílicos em Belo Horizonte sāo apresentados. História prévia de exposição a componentes acelulares do sangue foi determinada para o período de 5 anos anteriores à entrada no estudo, que transcorreu durante 1986 e 1987. Pacientes com distúrbios da coagulaçāo (hemofilia $\mathrm{A} n=132$, hemofilia $\mathrm{B} n=16 \mathrm{e}$ outros distúrbios da coagulaçāo que não hemofilia $n=16$ ), foram transfundidos com crioprecipitado líquido, localmente produzido, crioprecipitado liofilizado, importado de São Paulo, e Fator VIII e IX, importado do Rio de Janeiro, Europa e Estados Unidos. Trinta e seis (22\%) resultaram soropositivos para o VIH. A análise univariada e multivariada (regressão logística) demonstrou que o risco de infecção pelo VIH durante o período estudado, esteve associado ao total de unidades de componentes acelulares do sangue transfundidas. Além disto, a contribuição proporcional dos componentes individuais para o total de unidades acelulares transfundidas, isto é, um aumento na proporção de Fator VIII/IX e crioprecipitado liofilizado, demonstrou-se estar associado à soropositividade para o VIH. Este estudo sugere que nāo apenas a quantidade total de unidades transfundidas foi um importante determinante de soropositividade para o VIH, mas que o risco esteve também associado com o componente específico do sangue que foi transfundido. 
PROIETTI, F. A.; PROIETTI, A. B. F. C.; COSTA, M. F. F. L.; ANTUNES, C. M. F.; GUIMARĀES, M. D. C.; PAULINO, U. H. M.; SOUZA, C. J. C.; MELO, L. \& MUÑOZ, A. - Exposure to acellular blood products and risk of HIV infection in hemophiliacs from Belo Horizonte, Brazil. Rev. Inst. Med. trop. S. Paulo, 34(3): 227.232, 1992.

\section{REFERENCES}

1. BRESLOW, N. E. \& DAY, N. E. - Statistical methods in cancer research. Vol. 1 - The analysis of case-control studies. Lyon, International Agency for Research on Cancer, 1980 (IARC Scientific Publication No. 32).

2. COSTA, M. F. F. L.; OLIVEIRA, M. R.; OLIVEIRA, E. I.; PAUlino. U. H. M.; GRECO, D. B.; CHIARI, C. A.; GUIMARÁES, M. D. C.; PROIETTI, F. A.; ANTUNES, C. M. F. \& MUNOZ, A. - Factors associated with AIDS and AIDS like syndrome among homosexual men in Minas Gerais, Brazil. Int. J. Epidem., 19: 429-434, 1990.

3. DESFORGES, J. F. - AIDS and preventive treatment in hemophilia. New Eng1. J. Med., 308: 94-95, 1983.

4. EVATT, B. L.; GOMPERTZ, E. D.; MCDOUGAL, J. S. \& RAMSEY, R. B. - Coincidental appearance of LAV/ HTLV-III antibodies in hemophiltacs and the onset of the AIDS epidemic. New Eng. J. Med., 312: 483-486, 1985.

5. KOERPER, M. A.; KAMINSKY, L. S. \& LEVY, J. A. Differential prevalence of antibody to AIDS - associated retrovirus in hemophiliacs treated with factor VIII concentrate versus cryoprecipitate: recovery of infectious virus. Lancet, 1: 275, 1985.

6. LEDERMAN, M. M.; RATNOFF, O. D.; EVATT, B. L. \& MCDOUGAL, J. S. - Acquisition of antibody to lympha denopathy-associated virus in patients with classic hemo- philia (Factor VIII deficiency). Ann. intern. Med., 102: 753-757, 1985 .

7. MELBYE, M.; FROEBEL, K. S.; MADHOK, R.; BIGGAR, K. S.; SARIN, P. S.; STENBJERG, S.; LOWE, G. D. O.; FORBES, C. D.; GOEDERT, J.J.; GALLO, R.C. \& EBBESEN, J. J. - HTLV-III seropositivity in European hemophiliac exposed to factor VIII concen trated imported from the USA. Lancet, 2: 1444-1446, 1984.

8. PNEUMOCYSTIS CARINII pneumonia among persons with hemophilia A. MMWR, 31: 644-652, 1982.

9. RAGNU, M. V.; TEGMATIER, Q. E.; LEVY, J. A.; KAMINSKY, L. S.; LEWIS, J. H.; SPERO, J. A.; BONTEMPO, F. A.; HANDWERK-LEBER, C.; BAYER, W. L.; ZIMMERMAN, D. H. \& BRITZ, J. A. - AIDS retrovirus in remophiliacs treated with factor VIII or factor IX concentrates, cryoprecipitate or fresh frozen plasma: prevalence, seroconversion rate and clinical correlations. Blood, 67: $592-595,1986$.

10. RAMSEY, R. B.; PALMER, E. L.; MCDOUGAL, J. S.; KALYANARAMAN, V. S.; JACKSON, D. W.; CHORBA, T. L.; HOLAMN, R. C. \& EVATT, B. L. - Antibody to lymphadenopathy-associated virus in hemophiliacs with and without AIDS. Lancet, 2: 397-398, 1984.

Recebido para publicaçảo em 23/9/1991. Aceito para publicaçáo em 26/11/1991. 